\title{
Nutritional associations among fauna at hydrocarbon seep communities in the Gulf of Mexico
}

\author{
Stephen E. MacAvoy ${ }^{1,2, *}$ Charles R. Fisher ${ }^{3}$, Robert S. Carney ${ }^{4}$, Stephen A. Macko ${ }^{2}$ \\ ${ }^{1}$ Biology Department, American University, Washington, DC 20016, USA \\ ${ }^{2}$ Department of Environmental Sciences, University of Virginia, Charlottesville, Virginia 22903, USA \\ ${ }^{3}$ Biology Department, Pennsylvania State University, University Park, Pennsylvania 16802, USA \\ ${ }^{4}$ Coastal Studies Institute, Louisiana State University, Baton Rouge, Louisiana 70803, USA
}

\begin{abstract}
The Gulf of Mexico supports dense aggregations of megafauna associated with hydrocarbon seeps on the Louisiana Slope. The visually dominant megafauna at the seeps - mussels and tube worms - derive their nutrition from symbiotic relationships with sulfide or methane-oxidizing bacteria. The structure of the tube worm aggregations provide biogenic habitat for numerous species of heterotrophic animals. Carbon, nitrogen and sulfur stable isotope analyses of heterotrophic fauna collected with tube worm aggregations in the Green Canyon Lease area (GC 185) indicate that most of these species derive the bulk of their nutrition from chemoautolithotrophic sources. The isotope analyses also indicate that although 2 species may be deriving significant nutritional input from the bivalves, none of the species analyzed were feeding directly on the tube worms. Grazing gastropods and deposit-feeding sipunculids were used to estimate the isotopic value of the free-living chemoautolithotrophic bacteria associated with the tube worms $\left(\delta^{13} \mathrm{C}-32\right.$ to $-20 \%$; $\delta^{15} \mathrm{~N} 0$ to $7 \%$; $\delta^{34} \mathrm{~S}-14$ to $-1 \%$ ). The use of tissue $\delta^{34} \mathrm{~S}$ analyses in conjunction with tissue $\delta^{13} \mathrm{C}$ and $\delta^{15} \mathrm{~N}$ led to several insights into the trophic biology of the communities that would not have been evident from tissue stable $\mathrm{C}$ and $\mathrm{N}$ analyses alone.
\end{abstract}

KEY WORDS: Hydrocarbon seeps $\cdot$ Chemosynthesis $\cdot$ Sulfur isotopes Resale or republication not permitted without written consent of the publisher

\section{INTRODUCTION}

During trawls in the Green Canyon Lease area off the coast of Louisiana in 1985, previously unknown species of tube worms and bivalves were discovered near areas of seeping hydrocarbons and reduced sulfur gases (Kennicutt et al. 1985, Brooks et al. 1987). The Green Canyon tube worm and mussel species resembled the invertebrate species that had been discovered near hydrothermal vents in the late 1970s (Ballard 1977, Corliss \& Ballard 1977). The hydrothermal vent invertebrates contained symbiotic chemoautotrophic bacteria that oxidized reduced sulfur species for energy (reviewed by Childress \& Fisher 1992). Because the worms and bivalves found at the hydrocarbon seeps were related to the hydrothermal vent invertebrates and occurred at high densities around the seeps, it was postulated that they contained sym- biotic bacteria similar to those in the hydrothermal system (Kennicutt et al. 1985). It was soon discovered that the tube worms (Seepiophila jonesi and Lamellibrachia luymesi) and clams (Calyptogena ponderosa, Lucinoma atlantis and Vesicomya cordata) harbored symbiotic sulfide-oxidizing chemoautolithotrophic bacteria and the dominant mussel (Bathymodiolus childressi) was symbiotic with methanotrophic bacteria (Childress et al. 1986, Brooks et al. 1987, Gardinar et al. 2001). Subsequently, another mussel was discovered (Tamu fisheri) that harbors chemoautolithotrophic sulfuroxidizing symbionts (Fisher 1993). Free-living bacteria also abound in the seep environment, often forming large orange, yellow and white mats (MacDonald et al. 1989). It is generally believed that chemosynthetic primary production forms the base of the hydrocarbon seep community food web, although contributions from photosynthetically derived organic matter may 
occur (Page et al. 1990, Kennicutt et al. 1992, Conway et al. 1994, Carney 1994, Fisher 1996, Pile \& Young 1999, Levin \& Michener 2002).

The methane and other reduced carbon compounds in the shallow sediments at this site largely derive from seepage from deeper source rocks (MacDonald et al. 1990, Sassen et al. 1999). The $\mathrm{H}_{2} \mathrm{~S}$ is apparently largely produced by anaerobic sulfate-reducing bacteria in the shallow sediments and is linked to methane oxidation and possibly the oxidation of higher molecular weight hydrocarbons (Formolo et al. 2004, Joye et al. 2004, Sassen et al. 2004), but some sulfides may also be associated with the oil reservoir seepage (MacDonald et al. 1989). The sediments may release some $\mathrm{CH}_{4}$, $\mathrm{H}_{2} \mathrm{~S}, \mathrm{~S}_{2} \mathrm{O}_{3}{ }^{2-}$ and $\mathrm{NH}_{4}{ }^{+}$into the water column (Conway et al. 1994), however, these compounds are only abundant at or below the sediment-water interface (Julian et al. 1999, Freytag et al. 2001). The carbon sources for the thiotrophic and methanotrophic bacteria are different. The carbon source for the thiotrophic bacteria is dissolved inorganic carbon (DIC), while the methanotrophic bacteria use $\mathrm{CH}_{4}$ as both a carbon and energy source (Smith \& Hoare 1977, Colby et al. 1979, Cary et al. 1988).

Stable isotope analyses have played an important role in understanding hydrothermal vent and hydrocarbon seep ecosystems. In fact, the first real evidence that the nutrition of vent animals was based on local primary production rather than photosynthetic production were stable $\mathrm{C}$ and $\mathrm{N}$ analyses (Rau \& Hedges 1979, Rau 1981). Similarly, stable isotopes were important in determining the carbon and energy sources for symbiont-containing hydrocarbon seep fauna (Childress et al. 1986, Brooks et al. 1987, Fisher et al. 1993). Stable isotopes have also been a valuable tool for understanding trophic relationships among heterotrophic organisms within hydrothermal vent communities (Van Dover \& Fry 1989, 1994, Fisher et al. 1994). Nitrogen isotopes are good indicators of food chain position (an approximately 3.4\%o enrichment per trophic level; Minagawa \& Wada 1984), and carbon and sulfur isotopes have been shown to closely reflect an animal's food source (Fry \& Sherr 1984, Peterson et al. 1985, Peterson \& Howarth 1987, Hesslein et al. 1989, 1991, Kline et al. 1990, 1993, MacAvoy et al. 1998). The invertebrate and vertebrate taxa collected and observed among the chemoautolithotrophic animals at hydrocarbon seeps in the Gulf of Mexico are a fairly diverse group, including crabs, shrimp, isopods, gastropods, polychaete worms and fish (MacDonald et al. 1989, Carney 1994, Bergquist et al. 2003). To date, stable isotopic analyses have only been reported for a limited number heterotrophic species from the Gulf of Mexico seeps (Brooks et al. 1987, Fisher 1996, MacAvoy et al. 2002) and the nutritional relations among the seep fauna are not well understood.

In this study, tissue $\delta^{13} \mathrm{C}, \delta^{15} \mathrm{~N}$ and $\delta^{34} \mathrm{~S}$ analyses were used to investigate trophic linkages among the invertebrate fauna closely associated with tube worm aggregations located at hydrocarbon seeps off the coast of Louisiana (550 $\mathrm{m}$ depth). There were 4 primary objectives of this study: (1) To determine whether heterotrophic seep fauna collected with tube worms derived the bulk of their nutrition from chemoautolithotrophic or methanotrophic primary production. (2) to determine whether the symbiontcontaining invertebrates were an important food source for heterotrophs closely associated with the vestimentiferans. (3) to determine if analyses of tissue $\delta^{34} \mathrm{~S}$ values provided additional insights into trophic relations among seep fauna, beyond what could be learned from analysis of $\delta^{13} \mathrm{C}$ and $\delta^{15} \mathrm{~N}$. (4) To constrain the stable C, $\mathrm{N}$, and $\mathrm{S}$ values of free-living seep bacteria consumed by heterotrophic primary consumers.

\section{MATERIALS AND METHODS}

The Green Canyon Lease Area occupies approximately $22000 \mathrm{~km}^{2}$ of seafloor lying between the 200 and $2400 \mathrm{~m}$ isobaths on the topographically and geochemically complex continental slope off the coast of Louisiana. For the management of oil and gas development, the area is subdivided into $4.8 \times 4.8 \mathrm{~km}$ lease blocks. This study was conducted on communities from one of these lease blocks (GC 185; Bush Hill, located at $27^{\circ} 46.96^{\prime} \mathrm{N}, 91^{\circ} 30.46^{\prime} \mathrm{W}, 540$ to $580 \mathrm{~m}$ b.s.l.). GC 185 is an active hydrocarbon seep area supporting chemoautolithotrophic communities that have been studied for various purposes for more than a decade (Brooks et al. 1987, Kennicutt et al. 1992, Fisher 1996, Sassen et al. 1999). Tube worms are the visually dominant symbiont-containing group at the site, although mussels symbiotic with thiotrophic or methanotrophic bacteria (Tamu fisheri and Bathymodiolus childressi, respectively) also occur here. Methane and oil are actively seeping from the sediments in several places on Bush Hill. Bacterial mats and carbonate outcrops are abundant, as are shallow gas hydrates (Nix et al. 1995, Sassen \& Macdonald 1997, Sassen et al. 1999).

Isotope analysis. Two tube worm aggregations were collected intact with the DSV Johnson-Sea-Link II (Harbor Branch Oceanographic, Fort Pierce, FL) using a hydraulically activated device that encloses the tube worms and associated fauna, and removes the entire aggregation (Bushmaster Jr., Bergquist et al. 2000). One aggregation was dominated by larger individuals with no recent tube worm recruits present and is here- 
after referred to as the older aggregation $(\mathrm{BH}-7$ in Bergquist et al. 2002). The second younger aggregation (BH-1 in Bergquist et al. 2002) was dominated by small individuals, tube worm recruitment was recent or ongoing at the time of collection, and the mean tube worm age in the aggregation was calculated to be $3 \mathrm{yr}$ (Bergquist et al. 2002). Tissue samples were dissected at sea from all animals and were frozen until shipment to the stable isotope laboratory. The tissue type sampled was muscle tissue for most invertebrates, exceptions being the tube worms and mussels (plume tissue and mantle tissue were used, respectively). Samples arriving at the laboratory were thawed, dried at $60^{\circ} \mathrm{C}$ for $3 \mathrm{~d}$ and homogenized by a mortar-and-pestle grinding tool. Approximately 5 to $6 \mathrm{mg}$ of tissue was used for $\delta^{34} \mathrm{~S}$ measurements (1 to $2 \mathrm{mg}$ was used for tube worm plumes owing to the high sulfur content) and 0.6 to $1.0 \mathrm{mg}$ was used for $\delta^{13} \mathrm{C}$ and $\delta^{15} \mathrm{~N}$ measurements. A Carlo Erba elemental analyzer coupled to a Micromass Optima isotope ratio mass spectrometer (Micromass) was used to obtain $\delta^{13} \mathrm{C}, \delta^{15} \mathrm{~N}$ and $\delta^{34} \mathrm{~S}$ values (Fry et al. 1992, Giesemann et al. 1994). The $\delta^{13} \mathrm{C}$ and $\delta^{15} \mathrm{~N}$ values were determined concurrently and $\delta^{34} \mathrm{~S}$ was determined during separate analysis runs.

The isotope compositions are reported relative to standard material and follow the same procedure for all stable isotopic measurements as follows:

$$
\delta^{\mathrm{x}} \mathrm{E}=\left[\left({ }^{\mathrm{x}} \mathrm{E} /{ }^{\mathrm{y}} \mathrm{E}\right)_{\text {sample }} /\left({ }^{\mathrm{x}} \mathrm{E} /{ }^{\mathrm{y}} \mathrm{E}\right)_{\text {standard }}-1\right] \times 1000
$$

where $\mathrm{E}$ is the element analyzed $(\mathrm{C}, \mathrm{N}$ or $\mathrm{S}), \mathrm{x}$ is the molecular weight of the heavier isotope, and $\mathrm{y}$ the lighter isotope $(\mathrm{x}=13,15,34$ and $\mathrm{y}=12,14,32$ for $\mathrm{C}, \mathrm{N}$ and $\mathrm{S}$, respectively). The standard materials to which the samples are compared are PDB for carbon, air $\mathrm{N}_{2}$ for nitrogen and CDT for sulfur. Reproducibility of all measurements was typically $0.3 \%$ for $\delta^{34} \mathrm{~S}$ and $0.2 \%$ for $\delta^{13} \mathrm{C}$ and $\delta^{15} \mathrm{~N}$. Approximately 217 analyses were conducted using 84 individuals from 24 different species.

Statistical analysis. Mann-Whitney $U$-tests were used for 2 group comparisons and Kruskal-Wallace tests were used for all multiple comparisons ( $\alpha=0.05)$. The Dunn procedure was used to compare specific differences among groups if Kruskal-Wallis indicated a significant difference (Rosner 1990). The Dunn procedure reduces the risk of Type 1 error inherent in multiple comparison techniques by increasing the Z-score needed to reject the null hypothesis as the number of individual groups (treatments) increases. The statistical comparisons were only made when individual groups (treatments) had an
$\mathrm{N} \geq 3$. Microsoft Excel 5.0 (Microsoft) and Statview SE + Graphics (Abacus Concepts) were used for individual statistical tests.

\section{RESULTS}

\section{Chemoautolithotrophic symbiont-containing invertebrates}

In 1998, 2 separate tube worm aggregations were collected at GC 185 (Bush Hill). Two tube worm species, Lamellibrachia luymesi and Seepiophila jonesi, were present in both collections, and the younger aggregation also included the mussels Tamu fisheri and Bathymodiolus childressi. The B. childressi mussel is symbiotic with methanotrophic bacteria; however, it retains a functional gut and is capable of filter feeding (Page et al. 1990, Pile \& Young 1999). The other 3 symbiont-containing species harbor sulfur-oxidizing bacteria.

Tube worms were significantly ${ }^{13} \mathrm{C}$-enriched relative to both mussel species (Table 1). Bathymodiolus childressi and Seepiophila jonesi $\delta^{15} \mathrm{~N}$ values were not significantly different from each other, but were significantly different from Lamellibrachia luymesi and Tamu fisheri. L. luymesi were ${ }^{34} \mathrm{~S}$-depleted relative to $B$. childressi (Table 1). T. fisheri $\delta^{34} \mathrm{~S}$ values fell between those of L. luymesi and B. childressi, however, $T$. fisheri were not significantly different from either group $(0.1<\mathrm{p}>0.05)$.

\section{Heterotrophs}

Likely consumers of primary production (chemosynthetic or photosynthetic) are grazing gastropods and deposit feeders. Most grazing gastropods, which were collected from the young tube worm aggregation, were depleted in ${ }^{13} \mathrm{C}$ relative to that typically seen in Gulf of Mexico (GOM) particulate organic matter

Table 1. Isotope values for invertebrates with symbionts collected at GC 185. Comparisons were made within the collection, not between the collections. Those with different letters are significantly different from each other $(p \leq 0.05)$

\begin{tabular}{|lrrr|}
\hline Invertebrate & $\delta^{13} \mathrm{C} \pm \mathrm{SD}(\mathrm{N})$ & $\delta^{15} \mathrm{~N} \pm \mathrm{SD}(\mathrm{N})$ & $\delta^{34} \mathrm{~S} \pm \mathrm{SD}(\mathrm{N})$ \\
\hline Old tube worm bush & & & \\
Lamellibrachia luymesi & $-20.1 \pm 1.2(6) \mathrm{a}$ & $2.2 \pm 0.4(6) \mathrm{a}$ & $-27.2 \pm 5.8(4) \mathrm{a}$ \\
Seepiophila jonesi & $-22.0 \pm 0.4(5) \mathrm{b}$ & $3.2 \pm 0.6(5) \mathrm{b}$ & $-32.8 \pm 3.0(3) \mathrm{a}$ \\
Young tube worm bush & & & \\
Lamellibrachia luymesi & $-21.5 \pm 1.2(6) \mathrm{a}$ & $0.7 \pm 0.7(6) \mathrm{a}$ & $-25.1 \pm 2.4(5) \mathrm{a}$ \\
Seepiophila jonesi & $-22.2 \pm 2.3(4) \mathrm{a}$ & $3.8 \pm 1.3(4) \mathrm{b}$ & \\
Tamu fisheri & $-37.3 \pm 0.9(3) \mathrm{b}$ & $-0.4 \pm 1.8(3) \mathrm{a}$ & $-16.9 \pm 1.9(3) \mathrm{a}, \mathrm{b}$ \\
Bathymodiolus childressi & $-42.9 \pm 1.5(6) \mathrm{b}$ & $6.1 \pm 1.2(6) \mathrm{b}$ & $-5.3 \pm 1.4(6) \mathrm{b}$ \\
\hline
\end{tabular}



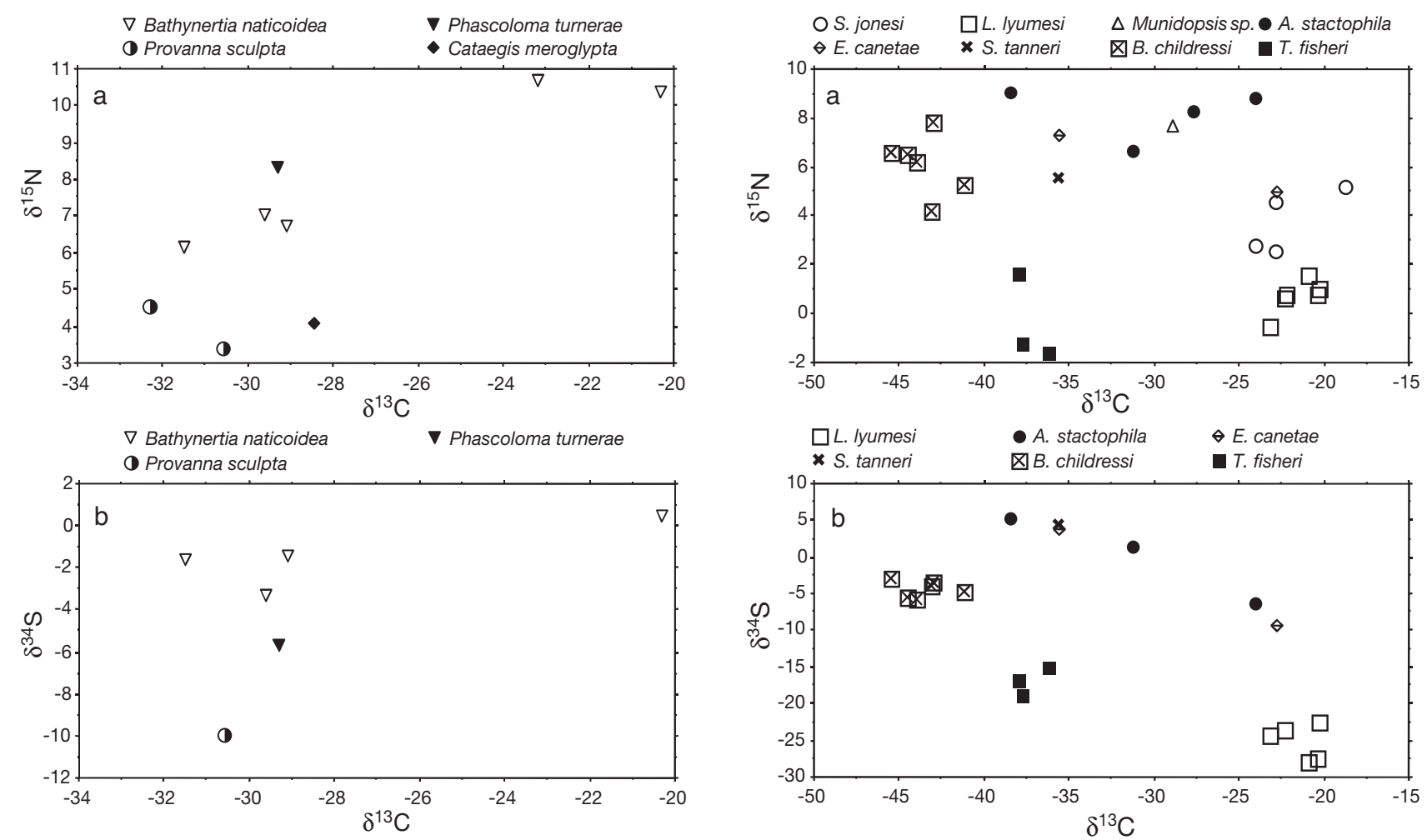

Fig. 1. $\delta^{13} \mathrm{C}$ vs. (a) $\delta^{15} \mathrm{~N}$ and (b) $\delta^{34} \mathrm{~S}$ for grazing gastropods associated with a young tube worm bush at GC 185

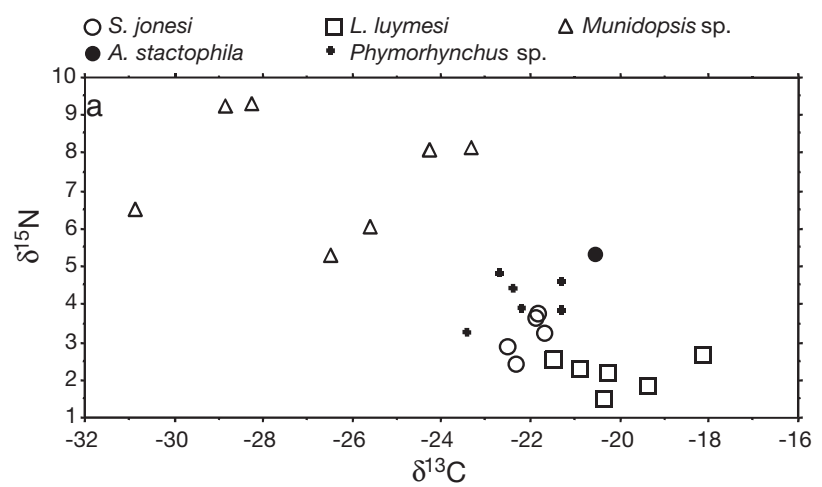

Fig. 3. $\delta^{13} \mathrm{C}$ vs. (a) $\delta^{15} \mathrm{~N}$ and (b) $\delta^{34} \mathrm{~S}$ for a subset of invertebrates closely associated with a young tube worm bush at GC 185

(POM, -21.4 \pm 1.4\%o; Fry 1983, Macko et al. 1984, although the tissue $\delta^{13} \mathrm{C}$ values for 2 individuals were in the range of values reported for POM (Fig. 1). The $\delta^{15} \mathrm{~N}$ values of the grazers ranged from 2 to $10 \%$, which tended to be somewhat lower than particulate organic matter $(7.5 \pm 0.8 \%$ ) and zooplankton $(8.9 \pm 0.9)$ in the NW GOM (Fry 1983, Macko et al. 1984). Sulfur in grazers as a group was highly ${ }^{34} \mathrm{~S}$-depleted relative to POM (marine POM $\delta^{34} \mathrm{~S}=18$ to $20 \%$; overlying GOM bottom waters $\delta^{34} \mathrm{~S}=20.3 \%$; Aharon \& Fu 2003), however, there was a $10 \%$ range among the 6 individuals analyzed (-10 to $0 \%$ ) (Fig. 1). The depositfeeding, primary-consumer sipunculid Phascolosoma turnerae lives in the sediment at the base of the tube worm aggregation. $P$. turnerae in both tube worm collections were depleted in ${ }^{13} \mathrm{C}$ and ${ }^{34} \mathrm{~S}$ relative to values expected for photosynthetic POM. P. turnerae isotope values were similar to those seen in grazing gastropods (Fig. 1, Table 2).

Most other invertebrate species captured within the tube worm aggregations were also ${ }^{34} \mathrm{~S}$-depleted relative to GOM POM (Table 2, Figs. $2 \& 3$ ). Nine of the other 14 species were ${ }^{13} \mathrm{C}$-depleted. The only individual not depleted in either ${ }^{13} \mathrm{C}$ or ${ }^{34} \mathrm{~S}$ relative to the other heterotrophs was a hagfish, Eptatretus sp. (Table 2 ). The 2 other vertebrates captured were a conger eel

Fig. $2 . \delta^{13} \mathrm{C}$ vs. (a) $\delta^{15} \mathrm{~N}$ and (b) $\delta^{34} \mathrm{~S}$ for a subset of invertebrates closely associated with an old tube worm bush at GC 185 
Table 2. Isotope values (means \pm standard deviation [N]) for hydrocarbon seep organisms captured in Bushmaster collections at GC 185

\begin{tabular}{|c|c|c|c|}
\hline Organism & $\delta^{13} \mathrm{C} \pm \mathrm{SD}(\mathrm{N})$ & $\delta^{15} \mathrm{~N} \pm \mathrm{SD}(\mathrm{N})$ & $\delta^{34} \mathrm{~S} \pm \mathrm{SD}(\mathrm{N})$ \\
\hline \multicolumn{4}{|l|}{ Old tube worm bush } \\
\hline \multicolumn{4}{|l|}{ Gastropods } \\
\hline Phymorhynchus sp. & $-22.2 \pm 0.8(6)$ & $4.1 \pm 0.6(6)$ & $4.6 \pm 6.6(4)$ \\
\hline Limpet & $-30.2 \pm 2.5(2)$ & $9.6 \pm 0.6(2)$ & $4.9(1)$ \\
\hline \multicolumn{4}{|l|}{ Worm-like taxa } \\
\hline Nemertean & $-23.1(1)$ & $7.5(1)$ & $-6.1(1)$ \\
\hline \multicolumn{4}{|l|}{ Crustacea } \\
\hline Munidopsis sp. & $-26.8 \pm 2.7(7)$ & $7.5 \pm 1.6(7)$ & $-4.4(1)$ \\
\hline Alvinocaris stactophila & $-20.6(1)$ & $5.4(1)$ & $-0.3(1)$ \\
\hline Ayiielae shrimp & $-33.2(1)$ & $2.6(1)$ & \\
\hline Atelecylidae crab & $-24.8(1)$ & $9.7(1)$ & \\
\hline \multicolumn{4}{|l|}{ Fish } \\
\hline Eptatretus sp. & $-20.9(1)$ & $11.5(1)$ & $12.2(1)$ \\
\hline Dysommina rugosa & $-30.4(1)$ & $7.4(1)$ & \\
\hline Ophicthus cruentifer & $-33.4(1)$ & $7.4(1)$ & $-13.3(1)$ \\
\hline \multicolumn{4}{|l|}{ Other } \\
\hline Phascolosoma turnerae & $-28.0 \pm 0.5(6)$ & $6.3 \pm 1.7(6)$ & $-7.6 \pm 3.8(4)$ \\
\hline Sclerasterias tanneri & $-32.9 \pm 0.5(2)$ & $5.5 \pm 0.1(2)$ & \\
\hline \multicolumn{4}{|l|}{ Younger tube worm bush } \\
\hline \multicolumn{4}{|l|}{ Gastropods } \\
\hline Provanna sculpta & $-31.5 \pm 1.2(2)$ & $4.0 \pm 0.8(2)$ & $-9.9(1)$ \\
\hline Cataegis meroglypta & $-28.5(1)$ & $4.1(1)$ & \\
\hline Eosipho canetae & $-29.2 \pm 9.1(2)$ & $6.2 \pm 1.6(2)$ & $-4.5 \pm 6.3(4)$ \\
\hline Bathynerita naticoidea & $-26.7 \pm 4.8(5)$ & $8.2 \pm 2.2(5)$ & $-1.5 \pm 1.4(4)$ \\
\hline \multicolumn{4}{|l|}{ Worm-like taxa } \\
\hline Red nemertean & $-22.2(1)$ & $-5.5(1)$ & $-9.6(1)$ \\
\hline Polynoid, Harmothoe sp. & $-23.6 \pm 0.1(2)$ & $5.7 \pm 1.9(2)$ & $-8.9 \pm 2.4(2)$ \\
\hline Polychaete (Amphinomidae) & $-40.9 \pm 0.9(3)$ & $8.1 \pm 2.0(3)$ & $-9.7 \pm 2.5(3)$ \\
\hline Maldanidae (Nicomache sp.) & $-28.5(1)$ & $7.5(1)$ & $-2.9(1)$ \\
\hline \multicolumn{4}{|l|}{ Crustacea } \\
\hline Munidopsis sp. & $-28.7(1)$ & $7.7(1)$ & $-7.5(1)$ \\
\hline Alvinocaris stactophila & $-30.4 \pm 6.2(4)$ & $8.2 \pm 1.1(4)$ & $0.9 \pm 5.3(4)$ \\
\hline \multicolumn{4}{|l|}{ Other } \\
\hline Phascolosoma turnerae & $-29.3(1)$ & $8.3(1)$ & $-3.2 \pm 3.5(2)$ \\
\hline Sclerasterias tanneri & $-35.6(1)$ & $5.5(1)$ & $4.2(1)$ \\
\hline
\end{tabular}

and the fact that stomach contents of animals that eat bacteria are almost impossible to characterize, especially hours after the animals are collected. Additionally, captured consumers often have a chance to eat damaged animals in the collection containers, so the most recent meal may not be indicative of their normal food source (authors' pers. obs.).

Stable isotopes cannot tell you what an animal has been eating; however they can constrain the possibilities, and sometimes tell you what an animal has not been eating, as well as provide general information on food sources. Because of the remoteness of the communities we are studying, stable isotopes are an excellent way to start, particularly with the addition of $\delta^{34} \mathrm{~S}$ to the more commonly reported $\delta^{13} \mathrm{C}$ and $\delta^{15} \mathrm{~N}$. This study provides basic information about what fuels the hydrocarbon seep communities in the Gulf of Mexico. However, our results must be interpreted within the context of what is known about the life history and feeding biology of the taxa, and tested by further research.

\section{Chemoautolithotrophic symbiont- containing invertebrates}

The tube worms in the collections were on the ${ }^{13} \mathrm{C}$-enriched side of the range of values that have been reported for these species on the

(Ophicthus cruentifer) and a cut throat eel (Dysommina rugosa). The 2 eels had tissue stable isotope values similar to many of the invertebrate heterotrophs collected with the same tube worm aggregations. However, the hagfish was the most ${ }^{13} \mathrm{C}-,{ }^{15} \mathrm{~N}-$ and ${ }^{34} \mathrm{~S}$-enriched of any animal captured (Table 2 ).

\section{DISCUSSION}

Very little is known about the feeding biology of most deep-sea animals, particularly the relatively newly discovered fauna of hydrocarbon seeps and hydrothermal vents. Much can be learned from behavioral observations and stomach content analyses, but these approaches are of limited use in these environments because of the difficulty of obtaining the former
Louisiana Slope (Brooks et al. 1987, Kennicutt et al. 1992). The fact that the tube worm species are ${ }^{13} \mathrm{C}$ enriched relative to the thiotrophic-symbiont-containing bivalve (Tamu fisheri) collected at the same site is consistent with patterns seen in hydrothermal vent communities. As with the hydrothermal vent tube worms and mussels, this difference is likely due to (1) the fact that the symbionts in the 2 groups use different forms of RibuloseBisPhosphate carboxylase/oxygenase (that fractionate to different extents), and (2) differences in morphology and physiology resulting in differential dissolved inorganic carbon (DIC) supply and exchange (Fisher et al. 1990, Robinson \& Cavanaugh 1995, Robinson et al. 1998, 2003). It is also possible that the 2 groups are taking up DIC that is quite different in $\delta^{13} \mathrm{C}$. In addition to the DIC in the seawater, inorganic $\mathrm{CO}_{2}$ can be produced from methane oxidation and 
degradation of organic material in the sediments or at the sediment-water interface. As a result, $\delta^{13} \mathrm{C}$ values for DIC in shallow sediments as low as $-27.3 \%$ have been reported for this site (Sassen et al. 1999). T. fisheri is a relatively small species that lives partially buried with its siphon very close to the sediment-water interface, where DIC $\delta^{13} \mathrm{C}$ values would reflect input from both interstitial and seawater sources. The 2 tube worm species could take up DIC either across their plumes (a well-vascularized gill-like gas exchange organ) or across their posterior ends (roots), which can be deeply buried in the sediment (Julian et al. 1999, Freytag et al. 2001). In the case of Seepiophila jonesi the plumes are located at the sediment-water interface while Lamellibrachia luymesi grows with its plume well above the sediment, up to a meter or more above the sediment in older aggregations (Bergquist et al. 2003). L. luymesi tissue carbon was significantly enriched in ${ }^{13} \mathrm{C}$ compared to $S$. jonesi in the older tube worm aggregation (Table 1). This is consistent with the plume being the primary DIC uptake organ and a relatively ${ }^{13} \mathrm{C}$-depleted DIC pool at the sediment surface interface as a result of methanotrophic activity in the sediments. The difference in $\delta^{13} \mathrm{C}$ values between species in the younger tube worm aggregation was not significant, but showed the same trend. The other mussel collected with one of the aggregations, Bathymodiolus childressi, harbors methanotrophic symbionts and its tissue $\delta^{13} \mathrm{C}$ values reflect the $\delta^{13} \mathrm{C}$ of methane at this site $(-44$ to $-46 \%$, Sassen et al. 1999).

As for carbon, differences between the tissue stable $\mathrm{N}$ isotope values in the 2 species of tube worms suggest that they are either utilizing different chemical species of $\mathrm{N}$, tapping different pools of $\mathrm{N}$, or discriminating differently after acquisition of their $\mathrm{N}$ source. We cannot distinguish between these possibilities at this time, but note that the different growth forms and resultant plume positions with respect to the sediments, described above for the 2 species, may contribute to this difference.

There is thought to be little fractionation between sulfide and sulfate or organic sulfur as a result of sulfide oxidation by chemoautolithotrophic bacteria (reviewed in Canfield 2001). Therefore, the tissue $\delta^{34} \mathrm{~S}$ values of animals with chemoautolithotrophic sulfuroxidizing symbionts probably reflect their reduced sulfur source. Although the $\delta^{34} \mathrm{~S}$ values of the 2 tube worm species were not significantly different, the averages were separated by $5 \%$, suggesting that they may be tapping different sulfide sources. Further analyses are needed to verify this trend. The mussel Tamu fisheri appears to be enriched in ${ }^{34} \mathrm{~S}$ compared to Lamellibrachia luymesi in the same aggregation, although the trend is not statistically significant. The trend towards a difference suggests that $T$. fisheri and L. luymesi may be acquiring sulfide from different pools. T. fisheri sulfide acquisition would be limited to the sedimentwater interface or at most a few centimeters deep into the sediments, and the trend of more ${ }^{34} \mathrm{~S}$ depletion in tissues of L. luymesi supports previous reports of sulfide uptake by root tissue (Freytag et al. 2001). Bathymodiolus childressi from the same collection as T. fisheri were on average even more enriched in ${ }^{34} \mathrm{~S}$, which is consistent with sulfur acquisition via a depleted sulfate pool by these methanotrophic symbiont-containing animals (average $\delta^{34} \mathrm{~S}=-16.9$ and $-5.3 \%$ for $T$. fisheri and B. childressi, respectively, $\mathrm{p}=0.02$; however, this was not significant using the Dunn procedure for individual comparisons within a Kruskal-Wallace test). It should be kept in mind, however, that $B$. childressi (and likely $T$. fisheri) are capable of filter feeding and so any of their tissue stable isotope values could be affected by input from other sources (Page et al. 1990, Pile \& Young 1999).

\section{Heterotrophs}

When all 3 stable isotopes are considered together, it is clear that all invertebrates collected in close association with the tube worm aggregations for this study are most likely obtaining the bulk of their nutrition from chemosynthetic production, as are 2 of the 3 fishes (Tables $1 \& 2$ ). In the cases where the $\delta^{13} \mathrm{C}$ and $\delta^{15} \mathrm{~N}$ values alone could not differentiate between input of photosynthetic and chemosynthetic material (Alvinocaris stactophila and Phymorhynchus sp. in the younger bush and a Nemertean and a polynoid worm in the older bush; Table 2), very depleted $\delta^{34} \mathrm{~S}$ values (relative to ambient bottom water sulfate [20.3\%o]; Aharon \& Fu 2003) clearly indicate the importance of local primary production to the nutrition of these species, although they are greatly ${ }^{34} \mathrm{~S}$-enriched relative to the tube worm tissues. These results are somewhat similar to those of Micheli et al. (2002) who found that at hydrothermal vents on the East Pacific Rise, predators closely associated with the tube worms derive a majority of their nutrition from chemosynthetic material. However, unlike some of the invertebrate heterotrophs examined in Micheli et al. (2002), which would consume tube worm tissue under their experimental conditions, the chemosynthetic production consumed by invertebrate heterotrophs at these cold seeps is unlikely to include tube worms. The $\delta^{34} \mathrm{~S}$ values of these organisms could indicate a mixing of ${ }^{34} \mathrm{~S}$ depleted chemosynthetic production and ${ }^{34} \mathrm{~S}$-enriched photosynthetic production, however, the $\delta^{34} \mathrm{~S}$ values are much too ${ }^{34} \mathrm{~S}$-enriched for tube worm tissue to be a primary source of nutrition. This is consistent with the 
observations of Kicklighter et al. (2004) who found that hydrocarbon seep tube worms (Seepiophila jonesi and Lamellibrachia luymesi) were unpalatable to predators such as mummichogs and the lesser blue crab. They propose that these tube worms either have chemical compounds in their tissues that deterred feeding (extracts of trophosome were unpalatable to both predators) or that the toughness of the tubes deterred predation. Lack of predation on tubeworms is also consistent with the long lives and great ages achieved by tube worms at these seeps (Bergquist et al. 2000, Cordes et al. 2003). The only species collected along with the tube worm aggregations that is not likely to obtain the bulk of its nutrition from chemoautotrophic production is the hagfish Eptatretus sp. (Table 2). This is consistent with the results of previous studies that examined the role of seep nutrition in a hagfish and a variety of other mobile benthic consumers in the Gulf of Mexico (MacAvoy et al. 2002, 2003).

The combined use of all 3 isotopes is also critical in evaluation of the possible role of the symbiontcontaining animals in the nutrition of the heterotrophic fauna. Based on $\delta^{13} \mathrm{C}$ and $\delta^{15} \mathrm{~N}$ values alone, one might erroneously conclude that the predatory/scavenging gastropod Phymorhynchus sp., and perhaps some individuals of the predatory Eosipho canetae and the grazing Bathynerita naticoidea, were feeding primarily on the tube worm-derived carbon and nitrogen. However, the very large difference between the tissue $\delta^{34} \mathrm{~S}$ values of the tube worms and these consumers indicate that this is very unlikely, although a mixed diet of tube worms and surface-derived material is consistent with the isotope data (Fig. 2a). Taken together, the $\delta^{13} \mathrm{C}$, $\delta^{15} \mathrm{~N}$ and $\delta^{34} \mathrm{~S}$ data also suggest that the only species that are likely to be obtaining significant dietary carbon and sulfur directly from the symbiont-containing bivalve species are the starfish Sclerasterias tanneri and the Amphinomid polychaete (Table 2). Micheli et al. (2002) found that hydrothermal vent mussels were also palatable to some invertebrate predators, particularly crabs. Munidopsis sp. and an Atelecylidid crab in this study had high tissue $\delta^{15} \mathrm{~N}$ values, reflecting their relatively high trophic level, however, their elevated $\delta^{34} \mathrm{~S}$ relative to tube worms, and high $\delta^{13} \mathrm{C}$ relative to mussels, indicate that neither of these chemoautotrophic-containing invertebrates was the dominant food item for these predators. This is further supported by Bergquist et al. (2003) who note that among the thousands of hydrocarbon seep tube worms examined in their study, none showed any signs of predation (unlike their observations in hydrothermal vent Ridgeia piscesae communities).

Based on what is known of isotopic discrimination between trophic levels, the feeding biology of some of the species analyzed, and the limited mobility of those species, one can constrain the range of stable isotope values in the free-living bacteria present on the tube worm tubes and in the sediment beneath the aggregation. This analysis is based on $1 \%$ enrichment associated with carbon, no enrichment associated with sulfur and 3\% enrichment associated with nitrogen per trophic level (Minagawa \& Wada 1984, Peterson \& Howarth 1987). The stable isotope values of the 3 grazing gastropods captured within the tube worm aggregation (Bathynerita naticoidea, Provanna sculpta and Cataegis meroglypta) suggest an isotope range for the material consumed off of tube worm tubes of -20 to $-32 \%$ C, 0 to $7 \%$ N, and -14 to $-1 \%$ S (Table 1, Fig. 1 ). The elevated $\delta^{15} \mathrm{~N}$ of some $B$. naticoidae relative to $P$. sculpta and $C$. meroglypta may reflect $B$. naticoidae's ability to consume small animals as well as bacteria as polychaete setae, crustacean legs and sponge spicules have been reported as gut contents for this species (Zande 1994, Zande \& Carney 2001). Very little is known about the ecology of $P$. sculpta (Waren \& Bouchet 2001) other than the fact that this small gastropod (usually $5 \mathrm{~mm}$ in length or less) is endemic to the Louisiana hydrocarbon seeps (Carney 1994) and that it probably grazes in a similar manner as C. meroglypta (Waren \& Bouchet 1993). Interestingly the tissue $\delta^{13} \mathrm{C}$ and $\delta^{15} \mathrm{~N}$ values of $P$. sculpta individuals grouped very tightly around $-32 \%$ and $4 \%$ respectively, and the 1 individual analyzed for $\delta^{34} \mathrm{~S}$, was very highly depleted in ${ }^{34} \mathrm{~S}$. Either this species is feeding very selectively on a specific population of the free-living bacteria present, or perhaps it has its own symbionts. The tissue $\delta^{13} \mathrm{C}, \delta^{15} \mathrm{~N}$ and $\delta^{34} \mathrm{~S}$ values of the depositfeeding sipunculid Phascolosoma turnerae suggest that the range of values of organic material present in the shallow sediments directly below the tube worm aggregations are -30 to $-28 \%$ C, 0 to $5 \%$ o $\mathrm{N}$ and -14 to $-2 \% \mathrm{~S}$ (Table 2 ). In addition to providing insights into the biology of some of the individual species present at the seeps, this study clearly demonstrates the power of using a third isotope (S) for trophic analysis of seep, and presumably hydrothermal vent, communities. Since the seep communities were discovered in 1985 (Kennicutt et al. 1985, Brooks et al. 1987) photographs and observations have indicated that some fauna were consistently associated with the seeps. The elevated biomass and presence suggested that the closely associated fauna would derive the bulk of their nutrition from local chemoautolithotrophic production, even though these communities are present in relatively shallow waters where input of photosynthetic material is likely to be significant. This study supports the hypothesis that fauna tightly associated with tube worm aggregations at cold seeps in the Gulf of Mexico obtains the bulk of its nutrition from local source of primary production. This study is consistent with previous 
stable isotope studies of hydrothermal vent communities in implicating free-living bacteria with a wide range of stable isotope values in the nutrition of the community (Fisher et al. 1994, Van Dover \& Fry 1994). Finally, this study suggests that the tube worms themselves are not an important source of nutrition for any of the species analyzed, a finding that is compatible with the very long lives of the seep vestimentiferans.

Acknowledgements. This work was supported in part by subcontracts L100094, S700033 and S70027 to the Mineral Management Service project RF-6899 and the Mineral Management Service, Gulf of Mexico Regional OCS office through contract \#1435-01-96-CT 30813. We would like to thank Dr. Ian MacDonald of the Geochemical and Environmental Research Group, Texas A\&M University, and Dr. Robert Avent of the Mineral Management Service for their interest and support. This research could not have been accomplished without the crews of the RV 'Edwin Link' and 'Johnson Sea Link' (Harbor Branch Oceanographic, Fort Pierce, FL). Special thanks to the Pennsylvania State University scientists for their help aboard the ship: Drs. Derk C. Berquest, John K. Freytag, Stephane Hourdez and Erin McMullen. Dr. Mary Rice (Smith Marine Station), Dr. Timothy Shank (Woods Hole Oceanographic), Dr. Julie Amber (Millersville University), Brett Begley (Pennsylvania State University), Dr. Stephane Hourdez (Equipe Ecophysiologie Station Biologique de Roscoff), Dr. Erin McMullen (Pennsylvania State University), and Rachel Kosoff (Pennsylvania State University) all assisted with species identification.

\section{LITERATURE CITED}

Aharon P, Fu BS (2003) Sulfur and oxygen isotopes of coeval sulfate-sulfide in pore fluids of cold seep sediments with sharp redox gradients. Chem Geol 195(1/4):201-218

Ballard RD (1977) Notes on a major oceanographic find. Oceanus 20:35-44

Bergquist DC, Williams FM, Fisher CR (2000) Longevity record for deep-sea invertebrate. Nature 403:499-500

Bergquist DC, Urcuyo IA, Fisher CR (2002) Establishment and persistence of seep vestimentiferan aggregations from the upper Louisiana slope of the Gulf of Mexico. Mar Ecol Prog Ser 241:89-98

Bergquist DC, Ward T, Cordes EE, McNelis T, Kosoff R, Hourdez S, Carney R, Fisher CR (2003) Community structure of vestimentiferan-generated habitat islands from upper Louisiana slope cold seeps. J Exp Mar Biol Ecol 289: 197-222

Brooks JM, Kennicutt MC II, Fisher CR, Macko SA, Cole K, Childress JJ, Bidigare RR, Vetter RD (1987) Deep-sea hydrocarbon seep communities: evidence for energy and nutritional carbon sources. Science 238:1138-1142

Canfield DE (2001) Biogeochemistry of sulfur isotopes. In: Stable isotope geochemistry. Rev Mineral Geochem 43: 607-636

Carney RC (1994) Consideration of the oasis analogy for chemosynthetic communities at Gulf of Mexico hydrocarbon vents. Geo-Mar Lett 14:149-159

Cary SC, Fisher CR, Felbeck H (1988) Mussel growth supported by methane as sole carbon and energy source. Science 240:78-80

Childress JJ, Fisher CR (1992) The biology of hydrothermal vent animals: physiology, biochemistry, and autotrophic symbioses. Oceanogr Mar Biol Annu Rev 30:337-441

Childress JJ, Fisher CR, Brooks JM, Kennicutt MC, Bidigare $\mathrm{R}$, Anderson A (1986) A methanotrophic marine molluscan symbiosis: mussels fueled by gas. Science 233:1306-1308

Colby J, Dalton H, Whittenbury R (1979) Biological and biochemical aspects of microbial growth on C-1 compounds. Annu Rev Microbiol 33:481-517

Conway NM, Kennicutt MC II, Van Dover CL (1994) Stable isotopes in the study of marine chemosynthetic-based ecosystems. In: Lajtha K, Michener RH (eds) Stable isotopes in ecology and environmental science. Blackwell Scientific Publications, Oxford, p 158-186

Cordes EE, Bergquist DC, Shea K, Fisher CR (2003) Hydrogen sulfide demand of long-lived vestimentiferan tube worm aggregations modifies the chemical environment at deepsea hydrocarbon seeps. Ecol Lett 6:212-219

Corliss JB, Ballard RD (1977) Oases of life in the cold abyss. Nat Geo 152:441-453

Fisher CR (1990) Chemoautotrophic and methanotrophic symbioses in marine invertebrates. Rev Aquat Sci 2: $399-436$

Fisher CR (1993) Oxidation of methane by deep-sea mytilids in the Gulf of Mexico. In: Oremland RS (ed) Biogeochemistry of global change: radiatively active trace gases. Chapman \& Hall, New York, p 606-618

Fisher CR (1996) Ecophysiology of primary production at deep-sea vents and seeps. In: Uiblein F, Ott J, Stachowtisch M (eds) Deep-sea and extreme shallow-water habitats: affinities and adaptations. Biosystematics Ecol Ser 11:313-333

Fisher CR, Kennicutt MC II, Brooks JM (1990) Stable carbon isotopic evidence for carbon limitation in hydrothermal vent vestimentiferans. Science 247:1094-1096

Fisher CR, Brooks JM, Vodenichar JS, Zande JM, Childressi JJ, Burke RA Jr (1993) The co-occurrence of methanotrophic and chemoautotrophic sulfur-oxidizing bacterial symbionts in a deep-sea mussel. PSZN I: Mar Ecol 14(4): $277-289$

Fisher CR, Childress JJ, Macko SA, Brooks JM (1994) Nutritional interactions at Galapagos hydrothermal vents: inferences from stable carbon and nitrogen isotopes. Mar Ecol Prog Ser 103:45-55

Formolo MJ, Lyons TW, Zhang CL, Kelley C, Sassen R, Horita J, Cole DR (2004) Quantifying carbon sources in the formation of authigenic carbonates at gas hydrate sites in the Gulf of Mexico. Chem Geol 205(3/4):253-264

Freytag JK, Girguis P, Bergquist DC, Andras JP, Childress JJ, Fisher CR (2001) Sulfide acquisition by roots of seep tube worms sustains net chemoautotrophy. Proc Natl Acad Sci USA 98:13408-13413

Fry B (1983) Fish and shrimp migrations in the northern Gulf of Mexico analyzed using stable $\mathrm{C}, \mathrm{N}$, and $\mathrm{S}$ isotope ratios. Fish Bull 81:789-801

Fry B, Sherr EB (1984) $\delta^{13} \mathrm{C}$ measurements as indicators of carbon flow in marine and freshwater ecosystems. Cont Mar Sci 27:13-47

Fry B, Brandt W, Mersch FJ, Tholke K, Garritt R (1992) Automated analysis system for coupled $\delta^{13} \mathrm{C}$ and $\delta^{15} \mathrm{~N}$ measurements. Anal Chem 64:288-291

Gardiner SL, McMullin E, Fisher CR (2001) Seepiophila jonesi, a new genus and species of vestimentiferan tube worm (Annelida: Pogonophora) from hydrocarbon seep communities in the Gulf of Mexico. Proc Biol Soc Wash 114:694-707

Giesemann A, Jager HJ, Norman AL, Krouse HR, Brand WA (1994) On-line sulfur isotope determination using a ele- 
mental analyser coupled to a mass spectrometer. Anal Chem 66:2816

Hesslein RH, Fox DE, Capel MJ (1989) Sulfur, carbon, and nitrogen isotopic composition of fish from the Macenzie River delta region and other arctic drainages. Can Data Rep Fish Aquat Sci 728:iv-11

Hesslein RH, Capel MJ, Fox DE, Hallard KA (1991) Stable isotopes of sulfur, carbon, and nitrogen as indicators of trophic level and fish migration in the lower Mackenzie River, Canada. Can J Fish Aquat Sci 48:2258-2265

Joye SB, Boetius A, Orcutt BN, Montoya JP, Schulz HN, Erickson MJ, Lugo SK (2004) The anaerobic oxidation of methane and sulfate reduction in sediments from Gulf of Mexico cold seeps. Chem Geol 205(3/4):219-238

Julian, D, Gaill F, Wood E, Arp AJ, Fisher CR (1999) Roots as a site of hydrogen sulfide uptake in the hydrocarbon seep Vestimentiferan Lamellibrachia sp. J Exp Biol 202(17): $2245-2257$

Kennicutt MC II, Brooks JM, Bidigare RR, Fay RR, Wade TL, McDonald TJ (1985) Vent-type taxa in a hydrocarbon seep region on the Louisiana slope. Nature 317:351-353

Kennicutt MC II, Burke RA, MacDonald IR, Brooks JM, Denoux GL, Macko SA (1992) Stable isotope partitioning in seep and vent organisms: chemical and ecological significance. Chem Geol 101:293-310

Kicklighter CE, Fisher CR, Hay ME (2004) Chemical defense of hydrothermal vent and hydrocarbon seep organisms: a preliminary assessment using shallow-water consumers. Mar Ecol Prog Ser 275:11-19

Kline TC, Goering JJ, Mathisen OA, Poe PH, Parker PL (1990) Recycling of elements transported upstream by runs of Pacific salmon. I. $\delta^{15} \mathrm{~N}$ and $\delta^{13} \mathrm{C}$ evidence in Sashin Creek, southeastern Alaska. Can J Fish Aquat Sci 47:136-144

Kline TC, Goering JJ, Mathisen OA, Poe PH, Parker PL (1993) Recycling of elements transported upstream by runs of Pacific salmon. II. $\delta^{15} \mathrm{~N}$ and $\delta^{13} \mathrm{C}$ evidence in the Kvichak River watershed, Bristol Bay southwestern Alaska. Can J Fish Aquat Sci 50:2350-2365

Levin LA, Michener R (2002) Isotopic evidence for chemosynthesis-based nutrition of macrobenthos: the lightness of being at Pacific methane seeps. Limnol Oceanogr 47: 1336-1345

MacAvoy SE, Macko SA, Garman GC (1998) Tracing marine biomass into tidal freshwater ecosystems using stable sulfur isotopes. Naturwissenschaften 85:544-546

MacAvoy SE, Carney RS, Fisher CR, Macko SA (2002) Use of chemosynthetic biomass by large, mobile, benthic predators in the Gulf of Mexico. Mar Ecol Prog Ser 225:65-78

MacAvoy SE, Macko SA, Carney RS (2003) Links between chemosynthetic production and mobile predators on the Louisiana continental slope: stable carbon isotopes of specific fatty acids. Chem Geol 201:229-237

MacDonald IR, Boland GS, Baker JS, Brooks JM, Kennicutt MC II, Bidigare R (1989) Gulf of Mexico hydrocarbon seep communities. Mar Biol 101:235-247

MacDonald IR, Reilly JF, Guinasso NL, Brooks JM, Carney RS, Bryant WA, Bright TJ (1990) Chemosynthetic mussels at a brine-filled pockmark in the northern Gulf of Mexico. Science 248:1096-1099

Macko SA, Entzeroth L, Parker PL (1984) Regional differences in nitrogen and carbon isotopes on the continental shelf of the Gulf of Mexico. Naturwissenschaften 71: 374-375

Micheli F, Peterson CH, Mullineaux LS, Fisher CR, Mills SW, Sancho G, Johnson GA, Lenihan HS (2002) Predation structures communities at deep-sea hydrothermal vents. Ecol Monogr 72(3):365-382
Minagawa M, Wada E (1984) Stepwise enrichment of ${ }^{15} \mathrm{~N}$ along food chains: further evidence and the relation between $\delta^{15} \mathrm{~N}$ and animal age. Geochim Cosmochim Acta 48:1135-1140

Nix ER, Fisher CR, Vodenichar J, Scott KM (1995) Physiological ecology of a mussel with methanotrophic endosymbionts at three hydrocarbon seep sites in the Gulf of Mexico. Mar Biol 122:605-617

Page HM, Fisher CR, Childress JJ (1990) The role of suspension-feeling in the nutritional biology of deep-sea mussel with methanotrophic symbionts. Mar Biol 104:251-257

Peterson BJ, Howarth RW (1987) Sulfur, carbon, and nitrogen isotopes used to trace organic matter flow in the saltmarsh estuaries of Sapelo Island, Georgia. Limnol Oceanogr 32(6):1195-1213

Peterson BJ, Howarth RW, Garritt RH (1985) Multiple stable isotopes used to trace the flow of organic matter in estuarine food webs. Science 227:1361-1363

Pile AJ, Young CM (1999) Plankton availability and retention efficiencies of cold-seep symbiotic mussels. Limnol Oceanogr 44(7):1833-1839

Rau GH (1981) Hydrothermal vent clam and tube worm ${ }^{13} \mathrm{C} /{ }^{12} \mathrm{C}$ : further evidence of nonphotosynthetic food sources. Science 213:338

Rau GH, Hedges JI (1979) Carbon-13 depletion in a hydrothermal vent mussel: suggestion of a chemosynthetic food source. Science 203:648-649

Robinson JJ, Cavanaugh CM (1995) Expressions of form I and II Rubisco in chemoautotrophic symbioses: implications for the interpretation of stable carbon isotopes values. Limnol Oceanogr 40(8):1496-1502

Robinson JJ, Polz MF, Fiala-Medioni A, Cavanaugh CM (1998) Physiological and immunological evidence for two distinct C1-utilizing pathways in Bathymodiolus puteoserpentis (Bivalvia: Mytilidae), a dual endosymbiotic mussel from the Mid-Atlantic Ridge. Mar Biol 132: 625-633

Robinson JJ, Scott KM, Swanson ST, Oleary H, Horken K, Tabita FR, Cavanaugh CM (2003) Kinetic isotope effect and characterization of form II RubisCO from the chemoautotrophic endosymbionts of the hydrothermal vent tube worm Riftia pachyptila. Limnol Oceanogr 48(1): $48-54$

Rosner B (1990) Fundamentals of biostatistics, 3rd edn. PWSKent Publishing, Boston, MA

Sassen R, MacDonald IR (1997) Hydrocarbons of experimental and natural gas hydrates, Gulf of Mexico continental slope. Org Geochem 26(3/4):289-293

Sassen R, Joye S, Sweet ST, DeFreitas DA, Milkov AV, MacDonald IR (1999) Thermogenic gas hydrates and hydrocarbon gases in complex chemosynthetic communities, Gulf of Mexico continental slope. Org Geochem 30: 485-497

Sassen R, Roberts HH, Carney R, Milkov AV, DeFreitas DA, Lanoil B, Zhang CL (2004) Free hydrocarbon gas, gas hydrate, and authigenic minerals in chemosynthetic communities of the northern Gulf of Mexico continental slope: relation to microbial processes. Chem Geol 205(3/4): 195-217

Smith AJ, Hoare DS (1977) Specialist phototrophs, lithotrophs: a unity among a diversity of prokaryotes? Bacteriol Rev 41:419-448

Van Dover CL, Fry B (1989) Stable isotopic compositions of hydrothermal vent organisms. Mar Biol 102:257-263

Van Dover CL, Fry B (1994) Microorganisms as food resources at deep-sea hydrothermal vents. Limnol Oceanogr 39(1): $51-57$ 
Waren A, Bouchet P (1993) New records, species, genera, and a new family of gastropods from hydrothermal vents and hydrocarbon seeps. Zool Scr 22(1):1-90

Waren A, Bouchet P (2001) Gastropoda and Monoplacophora from hydrothermal vents and seeps: new taxa and records. The Veliger 44:116-231

Zande JM (1994) Feeding and life history of the gastropod

Editorial responsibility: Otto Kinne (Editor-in-Chief),

Oldendorf/Luhe, Germany
Bathynerita naticoidea from Gulf of Mexico hydrocarbon seeps. MS thesis, Louisiana State University, Baton Rouge, LA

Zande JM, Carney RS (2001) Population size structure and feeding biology of Bathynerita naticoidea Clarke 1989 (Gastropoda: Neritacea) from Gulf of Mexico hydrocarbon seeps. Gulf Mex Sci 19:44-55

Submitted: April 6, 2004; Accepted: February 17, 2005 Proofs received from author(s): May 2, 2005 